\title{
DAMPAK PANDEMI COVID-19 TERHADAP SISTEM PEMBELAJARAN DI MADRASAH: SEBUAH META ANALISIS
}

\author{
Agus Jayadi ${ }^{1}$ \\ ${ }^{1}$ Universitas Pendidikan Mandalika \\ Email: agusjayadi@undikma2
}

\begin{abstract}
Abstrak
Di masa transisi covid-19 saat ini, berbagai sistem pembelajaran dapat digunakan tetapi, perlu dikaji dampak yang muncul akibat sistem tersebut. Penelitian ini menganalisis beberapa jurnal tentang dampak pembelajaran malaui sistem daring di masa pandemi covid-19 dengan menggunakan metode penelitian meta analisis. Hasil analisis mengungkapkan bahwa sistem daring belum berjalan secara maksimal. Selain itu masih terdapat kendala-kendala dalam pelaksanaannya yaitu terbatasnya kemampuan adaptasi dan penguasaan teknologi informasi oleh guru dan siswa, serta orang tua sebagai pendamping siswa di rumah, akses internet yang terbatas, sarana dan prasarana yang kurang memadai, seperti tidak semua siswa memiliki handphone androi, serta siswa masih merasa kesulitan berkomunikasi dengan guru dan temantemannya karena tidak semua siswa memiliki handphoen yang layak. Secara psikologi motivasi belajar siswa semakin menurun dan pembelajaran melalui daring seringkali membuat siswa menjadi bosen.

Katakunci: Pembelajaran, Daraing, Covid-19.
\end{abstract}

\section{PENDAHULUAN}

Pemerintah Indonesia menerapkan kebijakan tentang social distancing selama pandemi covid-19. Kebijakan ini membuat semua sektor menjadi tidak setabil tidak terkecuali sektor pendidikan. Salah satu dampak social distancing sistem pembelajaran di sekolah menjadi berubah. Akibatnya, kegiatan yang dilakukan di sekolah ditutup sementara untuk mencegah penyebaran dari virus corona. Hal ini dikuatkan dengan terbitnya Surat Edaran Nomor 4 Tahun 2020 menjelaskan tentang pelaksanaan belajar mengajar selama masa pandemi Covid-19.

Pada masa pandemi covid-19, aktivitas pembelajaan tetap berjalan seperti biasanya, hanya saja sistemnya yang berbeda, biasanya dilakukan dengan tatap muka diganti menjadi pembelajran daring. Sebagai contoh pemerintah Turki menyediakan pendidikan jarak jauh melalui platform dan siaran televisinya (Ozer, 2020). Hal ini dilakukan untuk selalu dapat meningkatkan kualitas pendidikan dan kompetensi siswa melalui pemanfaatan teknologi berbasis online. Upaya tersebut bertujuan untuk memutus rantai penularan virus corona. Virus corona merupakan sebuah virus yang penularannya sangat cepat dan sulit untuk mengidentifikasi ciri-ciri orang yang sudah terjangkit, karena masa inkubasi dari virus ini kurang lebih 14 hari.

Pada era revolusi industri 4.0, guru dan siswa diharuskan mampu memahami dan memanfaatkan teknologi dengan semaksimal mungkin sebagai media pembelajaran. Saat ini wabah virus corona masih melanda dunia pendidikan, sehingga pembelajaran harus dilakukan secara online, maka guru dan siswa harus mampu memanfaatkan teknologi tersebut sebagai sumber belajar agar pembelajaran dapat berjalan dengan lancar (Mahariyanti \& Suyanto, 2019).

Pemanfaatan media dalam proses pembelajaran merupakan salah satu yang harus dilakukan dan digunakan oleh guru untuk mempercepat proses pembelajaran menjadi lebih kondusif. Hal tersebut juga dianggap sebagai upaya dalam mengatasi suatu permasalahan yang terjadi dan dapat memaksimalkan di dalam pelaksanaan proses belajar mengajar (Darmawan (2014); Ramli (2012); (Rohmat, 2016). Prinsip-prinsip pemanfaatan juga dikaitkan dengan karakteristik pembelajar. Seseorang yang belajar mungkin memerlukan bantuan keterampilan visual atau verbal agar dapat menarik keuntungan dari praktik atau sumber belajar. Oleh karena itu, pembelajar perlu 
mempelajari bagaimana dapat menetapkan media pembelajaran agar mengefektifkan pencapaian tujuan pembelajaran dalam proses belajar mengajar.

Selain memanfaatkan media pembelajaran, bahan ajar memiliki suatu peranan yang sangat penting dalam pembelajaran. Bahan ajar merupakan seperangkat materi atau substansi pembelajaran yang telah disusun secara berurutan dan sitematis dan menampilkan suatu perwujudan dari kompetensi. Bahan ajar merupakan alat dan media yang memberikan kesempatan kepada siswa untuk memperoleh pengalaman belajar, pengetahuan dan sikap (Nurjaya. 2012; Siddiq. 2008).

Pembelajaran online telah dilakukan oleh semua sekolah tanpa terkecuali dengan menggunakan aplikasi pembelajaran. Tercatat ada 21 aplikasi yang dapat digunakan dalam pembelajaran diantaranya adalah rumah belajar, kipin school, meja kita, media belajar online, icando, cerebrum, google for education, brainly indonesia, indonesiax,kelas pintar, NF juara, microsoft office 365, quipper school, sekolahmu, zenius,cisco webex google class room, google meet, ruang guru, zoom, whatsapp dan lain sebagainya. Namun, dampak jangka pendek yang dirasakan oleh banyak masyarakat yaitu banyaknya masyarakat yang kurang familier melakukan sekolah di rumah (DBR) dan bagi guru dan siswa adalah khususnya yang tinggal di daearah pedesaan akses internet yang sangat minim dan sarana prasarana yang sangat terbatas.

Dengan sistem pembelajaran online ini juga akan muncul kerugian mendasar bagi siswa dan orangtua, misalnya adanya proses penilain internal yang dilakukan secara langsung oleh guru terhadap siswanya yang indikatornya tentang apektif dan psikomotorik siswa, tentu hal ini tidak bisa dilakukan. Penilaian internal dianggap sangat penting bagi orang tua dari siswa karena penilaian tersebut dapat memberikan informasi tentang perubahan yang terjadi dari anak-anak mereka dan apakah tujuannya dalam memberikan pendidikan kepada anaknya sudah tercapai atau belum. Hal ini sejalan dengan pendapatnya Popham (1995: 3) dalam Widoyoko bahwa asesmen dalam konteks pendidikan usaha secara formal untuk menentukan status siswa berkenaan dengan berbagai kepentingan pendidikan.

Berdasarkan uraian di atas, peneliti mengangap, hal ini menarik dilakukan pengkajian untuk mengetahui dampak dari pandemi covid- 19 terhadap sistem pembelajaran yang berlaku saat ini dengan menganalisis berbagai jurnal penelitian yang sudah dilakukan oleh peneliti lainnya.

\section{METODE PENELITIAN}

Penelitian ini menggunakan sistem literature review yaitu pencarian literatur nasional. Literature review ini dilakukan dengan menggunakan metode meta-analisis, sehingga memudahkan dalam meninjau struktur roadmap tujuan penelitian (Moher, et al., 2015). Meta analisis dalam literature review digunakan sebagai sumber empiris bukti, di mana penulis dapat meringkas dan menganalisis artikel (Amelia et al., 2019). Meta analisis juga dapat mendefinisikan artikel sesuai kualifikasinya, yang akan menjadi peran penting dalam memecahkan masalah dengan menjelaskan, mensintesis, dan menilai bukti kuantitatif atau kualitatif sebagai bahan pelaporan.

Proses sistematik literature review ini dilakukan melalui 3 tahap, yaitu terdiri dari pencarian dan pengambilan artikel, pemilteran dan penyortiran, dan analisis. 


\section{HASIL DAN PEMBAHASAN}

Wabah penyakit covid-19 membuat semua sektor menjadi lumpuh tak terkecuali sektor pendidikan, hal tersebut membuat proses pembelajaran menjadi tidak berjalan normal. Sistem pendidikan khususny di Indonesia terpaksa harus merubah haluan demi mengoptimalkan kondisi sekolah yang biasanya dilakukan dengan tatap muka diaganti menjadi sistem daring. Perubahan ini harus dilakukan oleh guru dan siswa sebagai salah satu upaya untuk memutus rantai penyebaran virus corona.

Pembelajaran melalui daring memiliki korelasi dengan konsep Kementerian Pendidikan dan Kebudayaan yang digaungkan oleh Nadiem Makarim sebelum pandemi covid-19 yang disebut dengan pembelajaran mandiri. Anak didik dituntut menguasai teknologi, kreatif, memiliki motivasi dan gairah belajar yang tinggi, mampu melakukan inovasi dengan target mempersiapkan milineal dalam menghadapi tantangan di era global (Fauzi \& Khusuma, 2020). Pada prinsipnya tujuan pemerintah tersebut sangat bagus tetapi perlu dikaji kembali, dampak yang akan muncul dari kalangan guru, siswa dan masyarakat.

Pembelajaran daring banyak mendatangkan manfaat, seperti pembelajaran lebih fleksibelitas, konten yang bervariasi, dan biaya rendah Olelewe \& Orji, (2019), untuk mewujudkan hal tersebut dengan kondisi saat ini media pembelajaran berbasis teknologi yang cocok adalah mobile learning yang mampu membuat pembelajaran menjadi menarik dan siswa tertarik untuk belajar yang dampaknya dapat membuat meningkatnya kemampuan literasi (Aulya \& Asikin, 2020). Namun dibalik manfaat yang dirasakan oleh guru dan siswa, ternyata masih terdapat berbagai kendala yang dihadapi pada pembelajaran berbasis daring tersebut (Olelewe \& Orji, 2019). Dengan sistem ini guru, siswa dan orang tua harus menyiapkan sarana dan prasarana seperti handphon (HP), juga kuota yang cukup agar pelaksanaan pembelajaran berjalan lancar.

Purwanto et al., (2020) mengungkapkan bahwa pembelajaran secara daring membutuhkan kuota yang cukup, sehingga menyebabkan pengeluaran orang tua juga akan meningkat dan adanya pekerjan tambahan bagi orang tua dalam mendampingi anak belajar, komunikasi dan sosialisasi antar siswa, guru dan orang tua menjadi berkurang. Pendapat senda juga diungkapkan oleh Amalia dan Nurus (2020) bahwa pembelajaran daring masih terdapat kendala yaitu terbatasnya kemampuan adaptasi dan penguasaan teknologi informasi oleh guru dan siswa, selain itu sarana dan prasarana yang kurang memadai, akses internet terbatas, dan kurangnya kemauan untuk menganggarkan. Berdasarkan pendapat di atas, maka untuk dapat mengikuti kegiatan pembelajaran dengan baik siswa harus menyiapan sarana dan prasarana yang tepat seperti handphon, kuota yang cukup, selain itu orang tua juga harus dapat mengatur waktunya untuk sedapat mungkin mengawasi dan menjadi pendamping, serta pembimbing bagi anaknya ketika proses pembelajaran berlangsung dengan menggunakan daring. Jika hal ini tidak dilakukan yang menjadi kehawatiran bersama adalah siswa tidak menggunakan media tersebut sesuai dengan kegunaannya.

Tidak hanya memiliki handphone yang bagus kurangnya jaringan intrnet juga dapat menjadi kendala dalam proses pembelajaran. Hal ini juga diungkapkan oleh Wijaya et al., (2020) bahwa kurangnya koneksi sinyal internet juga menjadi kendala selama proses pembelajaran daring . Kendala selanjutnya yaitu siswa belum terbiasa dengan pembelajaran daring karena selama ini sistem belajar dilaksanakan dengan tatap muka. Banyak siswa menganggap bahwa sekolah merupakan kegiatan yang sangat menyenangkan, mereka bisa berinteraksi satu sama lain. Di sekolah, siswa dapat meningkatkan keterampilan sosial dan kesadaran kelas sosial mereka. Sekolah secara 
keseluruhan adalah media interaksi antar siswa dan guru untuk meningkatkan kemampuan integensi, skill dan rasa kasih sayang diantara mereka (Caroline, 1979).

Dampak selanjutnya adalah guru kesulitan mengontrol dan membangun motivasi belajar kepada siswa karena ruang komunikasi terbatas yang pada akhirnya siswa merasa jenuh dengan pembelajaran daring. Mereka terbiasa berada di sekolah untuk berinteraksi dengan teman-teman maupun gurunya secara tatap muka. Hal ini juga senada dengan pendapatnya Mastura \& Santaria, (2020) bahwa kurangnya motivasi belajar siswa menyebabkan siswa cepat merasa jenuh dengan pembelajaran daring tersebut.

Selain pada diri siswa, dengan sistem daring ini juga terjadi pada guru bahwa beberapa guru di daerah tidak seluruhnya paham dalam menggunakan teknologi, hal ini bisa dilihat dari guru-guru yang lahir pada tahun sebelum 1980-an. Kemampuan mereka rata-rata di bawah standar, jikapun mereka mampu tentu membutuhkan waktu yang lama untuk mempelajarinya. Secara konsep mereka mampu namun karena ketidak mampuannya dalam menggunakan teknologi akan membuat sistem pemelajaran menjadi lambat. Kendala teknologi informasi membatasi mereka dalam menggunakan media daring karena guru-guru senior ini terbiasa dengan pembelajaran tatap muka (Syah, 2020). Kendala lain yang timbul adalah kurangnya akses internet yang menyebabkan terhambatnya proses pembelajaran serta tidak semua siswa dapat mengikuti pembelajaran secara online disebabkan karena kurangnya prasarana maupun koneksi internet yang kurang bagus (Wijaya et al., 2020).

Dengan adanya covid-19 ini pelaksanaan pembelajaran daring dapat disimpulkan masih belum optimal dalam penyampaian materi pembelajaran kepada siswa, hal ini disebabkan karena kemampaun guru dalam mengunakan teknologi masih terbatas guru terbiasa belajar di kelas secara face-to-face. Sehingga guru merasa bahwa pembelajaran menjadi tidak bermakna bagi siswa. Menurut pendapat Muspita dan Woro (2020), kendala yang dialami oleh siswa dan guru dalam kegiatan belajar mengajar online adalah kurangnya penguasaan teknologi baik oleh guru maupun siswa, selain itu penambahan biaya kuota internet, adanya pekerjan tambahan bagi orang tua dalam mendampingi anak belajar, komunikasi dan sosialisasi antar siswa, guru dan orang tua menjadi berkurang dan jam kerja yang menjadi tidak terbatas bagi guru karena harus berkomunikasi dan berkoordinasi dengan orang tua, guru lain, dan kepala sekolah.

Pelaksanaan pembelajaran secara daring tidak merata kepada seluruh siswa dan pembelajaran cenderung berpusat pada guru (teacher centered). Selain itu Mukminah dan Herjan (2020), mengungkapkan bahwa penerapan pembelajaran daring dirasakan kurang efektif, siswa mengalami kesulitan memahami materi melalui pembelajaran daring, ini disebabkan karena sulitnya interaksi secara langsung antara guru dan siswa, siswa cepat merasa bosan. Dengan sistem ini maka proses pembelajaran tidak dapat berjalan lancar, sehingga proses pembelajaran lebih difokuskan dalam bentuk penugasan kepada siswa (Satrianingrum \& Prasetyo, 2020). Hal ini terlihat ketika melakukan sebuah diskusi, ada beberapa siswa yang menjadi silence reader dan respon dari siswa pun sedikit lebih pendek.

Hal ini juga didukung oleh penelitian Mahariyanti, et.al., (2020) bahwa sistem pembelajaran yang dilakukan melalui sistem daring berdampak terhadap kepada siswa, guru dan orangtua. Mereka mengukapkan bahwa dengan sistem daring membuat motivasi belajar siswa mejadi rendah dan siswa cepat merasa jenuh. Selain itu pembelajaran daring berdampak terhadap guru terutama guru senior, mereka harus belajar lebih ekstra untuk dapat memahami dan memanfaatkan teknologi karena mereka 
terbiasa dengan pembelajaran tatap muka. Kurangnya koneksi internet menghambat pembelajaran secara daring, serta pembelajran dirasakan masih kurang optimal karena pelaksanaan pembelajaran secara daring tidak merata kepada seluruh siswa dan pembelajaran cenderung terpusat pada guru. Bagi orang tua pembelajaran melalui daring akan penambahan biaya yang digunakan untuk membeli pasilitas seperti handphon, kuota internet dan orang tua harus membagi waktu dengan aktifitas mereka sehari-hari untuk mendampingi anak-anak mereka selama pembelajaran daring berlangsung.

\section{KESIMPULAN}

Hasil penelitian menunjukan bahwa sisetem pembelajaran daring merupakan pembelajaran yang paling banyak digunakan disemua jenjang pendidikan dan sebagian besar dapat berjalan dengan baik. Meskipun demikian sistem daring dinilai belum maksimal dalam mengukur perkembangan hasil kompetensi siswa. Selain itu masih terdapat kendala-kendala dalam pelaksanaannya yaitu keterbatasan kemampuan adaptasi dan penguasaan teknologi informasi oleh guru dan siswa, serta orang tua sebagai pendamping siswa di rumah, selain itu sarana dan prasarana yang kurang memadai, akses internet yang terbatas, dan kurangnya kemauan orang tua untuk menganggarkan atau pengadaan sarana dan prasarana pembelajaran seperti handphon androi, serta siswa masih merasa kesulitan berkomunikasi dengan guru dan temantemannya karena tidak semua siswa memiliki handphon yang layak. Secara psikologi motivasi belajar siswa semakin menurun dan pembelajaran melalui daring seringkali membuat siswa menjadi bosen.

\section{DAFTAR PUSTAKA}

Ade Prasetia Cahyadi (2020). Problematika Pembelajaran Daring Problematika Pembelajaran Daring Di Masa Pandemi Covid-19 : (Studi Kasus Sekolah Tapal Batas Madrasah Ibtidaiyah Darul Furqon) Problems Of Online Learning During Covid-19 Pandemic In Darul Furqan Boarding School: a Case Study. Jurnal Borneo Humaniora Available Online At Jurnal.borneo.ac.id e-issn 2599-3305 p-issn 2615-4331 diterbitkan agustus 2020 halaman 85-91 http:// jurnal.borneo.ac.id/index.php/borneo_humaniora cahyadi a.p.

Amalia, Andina \& Nurus Sa'Adah (2020). Dampak Pandemi Covid-19 Terhadap Kegiatan Belajar Mengajar Di Indonesia. Jurnal Psikologi. Volume 13 No.2, Desember 2020. https://doi.org/10.35760/psi.2020.v13i2.3572.

Amelia, N., Abdullah, A. G., \& Mulyadi, Y. (2019). Meta-analysis of student performance assessment using fuzzy logic. Indonesian Journal of Science and Technology, 4(1), 74-88. https://doi.org/10.17509/ijost.v4i1.15804.

Auliya, N. M., Suyitno, A., \& Asikin, M. (2020). Potensi Mobile learning Berbasis Etnomatematika untuk Mengembangkan Kemampuan Literasi Matematis pada Masa Pandemi. Prosiding Seminar Nasional Pascasarjana UNNES. ISSN: 2686 6404.

Caroline Hodges Persell, 1979, Educations and Inequality, The Roots and Results of Strattification in America's Schools, United States of America: The Free Press.

Dahliana, D., Sembiring, S., Simanjuntak, W., 2013, Pengaruh Suhu Sintering Terhadap Karakteristik Fisis Komposit MgO-SiO2 Berbasis Silika Sekam Padi, Jurnal 
Teori dan Aplikasi Fisika, Vol. 01 no. 01, Program Studi Fisika Material, FMIPA, Universitas Lampung, Bandar Lampung.

Darmawan, D. (2014). Inovasi Pendidikan Pendekatan Praktik Teknologi Multimedia dan Pembelajaran Online. Bandung: PT Remaja Rosdakarya Offset.

Ericha Windhiyana Pratiwi (2020). Dampak Covid-19 Terhadap Kegiatan Pembelajaran Online Di Sebuah Perguruan Tinggi Kristen Di Indonesia. Jurnal Perspektif Ilmu Pendidikan. http://doi.org/10.21009/PIP.341.1 Volume 34 Issue 1 April 2020 p-ISSN: 1411-5255 e-ISSN: 2581-2297. DOI: doi.org/10.21009/PIP.341.1

Ermila Mahariyanti, dkk., (2020). Meta Analisis : Dampak Pandemi Covid-19 Terhadap Sistem Pembelajaran. NUSRA: Jurnal Penelitian dan Ilmu Pendidikan. Volume 1, Issue 2, November 2020. Homepage: ejournal.nusantaraglobal.ac.id/index.php/nusra p-ISSN: 2715-114X e-ISSN: 2723-4649. Https://penerbitdeepublish.com/aplikasi-pembelajaran-online.

Fauzi, I., \& Khusuma, I. H. S. (2020). Teachers' elementary school in online learning of COVID-19 pandemic conditions. Jurnal Iqra': Kajian Ilmu Pendidikan, 5(1), 58-70. https://doi.org/10.25217/ji.v5i1.914

Moher, D., Shamseer, L., Clarke, M., Ghersi, D., Liberati, A., Petticrew, M., Shekelle, P., Stewart, L. A., \& Group, P. (2015). Preferred reporting items for systematic review and meta-analysis protocols ( PRISMA-P) 2015 statement. 1-9.

Mukminah \& Herjan H. (2021). Dampak Covid-19 Terhadap Implementasi Embelajaran Daring Ilmu Pengetahuan Alam (Ipa) Di Madrasah Ibtidaiyah Nurul Iman Ujan Rintis Ijert: Indonesian Journal of Education Research and Technology. Vol. 1 No 1 Januari 2021. p-ISSN 2775-0698.

Muspita A dan Woro Sumarni (2020). Dampak Pandemi Covid 19 Terhadap siswa Kelas 2 Mi Al-Azhar Dharmasraya Seminar Nasional Pascasarjana 2020: Issn: 2686 6404. Universitas Negeri Semarang, Kelud Iii Petompon Gajahmungkur Kota Semarang, Kode Pos 50237, Indonesia.

Olelewe, C. J., \& Orji, C. T. (2019). Constraints and strategies for effective use of social networking sites ( snss ) for collaborative learning in tertiary institutions in nigeria : perception of tvet lecturers. Education and Information Technologies, $1-20$.

Ozer, M. (2020). The Contribution of the Strengthened Capacity of to the Fight against Covid19. Journal of org/10.2399/yod.20.726951.

Popham, W. J. (1995). Classroom assessment. Boston: Allyn and Bacon.

Purwanto, Agus, Dkk.(2020). Studi Eksploratif Dampak Pandemi Covid-19 Terhadap Proses Pembelajaran Online Di Sekolah Dasar. Journal Of Ecducation, Psychcology And Conceling. Volume 2 Nomor 1 (2020) Issn Online : 27164446.

Rahmi, R. (2020). Inovasi Pembelajaran Di Masa Pandemi Covid-19. Al-Tarbiyah: Jurnal Pendidikan (The Educational Journal), 30(2). Https://Doi.Org/Https://Www.Researchgate.Net/Profile/RinaRahmi/Publication/348005536_Inovasi_Pembelajaran_Di_Masa_Pandemi_Co vid-19/Links/5ff51c0c92851c13feefd6fc/Inovasi-Pembelajaran-Di-MasaPandemi-Covid-19.Pdf.

Rohmat. (2016). Memelihara Kualitas Proses Belajar Mengajar Berbasis Media. 
Jurnal Cahaya Mandalika, Vol. 2, No. 3, November 2021 ,e- ISSN: 2721-4796

Available online at: http://ojs.cahayamandalika.com/index.php/JCM

Copyright $@ 2021$ Published by: Institut Penelitian \& Pengembangan Mandalika Indonesia

Syah, R. H. (2020). Dampak Covid-19 pada Pendidikan di Indonesia: Sekolah, Keterampilan, dan Proses Pembelajaran. SALAM: Jurnal Sosial Dan Budaya Syar-I, 7(5). https://doi.org/10.15408/sjsbs.v7i5.15 314

Widoyoko, Eko Putro. 2015. Evaluasi Program Pembelajaran. Available on.http://www.umpwr.ac.id/download/publikasiilmiah/Evaluasi\%20Progra m\%20Pembelajaran.pdf. Diambil 12 Juni 2015.

Wijaya, R., Lukman, M., \& Yadewani, D. (2020). Dampak Pandemi Covid-19 Terhadap Pemanfaatan E-Learning. Dimensi, 9(2), 307-322. 